Kompiuterno-oriientovani systemy navchannia. Kyiv: NPU imeni M.P. Drahomanova, 2018. №20(27). S. 113-118.

4. Zhaldak M.I. Deiaki metodychni aspekty navchannia informatyky v shkoli i pedahohichnomu universyteti. Naukovyi chasopys NPU imeni MP Drahomanova. Seriia 2: Kompiuterno-oriientovani systemy navchannia. Kyiv: NPU imeni M.P.Drahomanova, 2005. № 9. S. 3-14.

5. Osnovy baz danykh. SUBD Access 2010 (2013). Posibnyk do vyvchennia ta praktychnoi roboty / D.A. Pokryshen ta in. Chernihiv: TOV NVP «Interservis», 2013. 225 s. (lyst MON No1/9-793 vid 11.11.2013)

6. Pokryshen D. A. Informatsiino-analitychni systemy $\mathrm{v}$ pidhotovtsi vchyteliv informatyky: monohrafiia. Chernih. obl. in-t pisliadyplom. ped. osvity im. K. D. Ushynskoho. Kyiv: Interservis, 2017. 378 s. : hraf., tabl.

7. Ramskyi Yu.S., Tsybko H.Iu. Proektuvannia i opratsiuvannia baz danykh: posibnyk dlia vchyteliv. Ternopil: Navchalna knyha-Bohdan, 2005. $116 \mathrm{~s}$.

8. Umryk M. A. Udoskonalennia systemy pidhotovky maibutnikh uchyteliv informatyky u sferi proektuvannia i opratsiuvannia baz danykh. Naukovyi chasopys NPU imeni M.P. Drahomanova. Seriia 2: Kompiuterno-oriientovani systemy navchannia. Kyiv: NPU imeni M.P. Drahomanova, 2012. № 12 (19). S. 71-76.

9. Tsybko H.Iu. Pidvyshchennia rivnia teoretychnoi pidhotovky $z$ informatyky na fizykomatematychnykh fakultetakh pedahohichnykh vuziv: Dys. kand. ped.nauk: 13.00.02 / NPU imeni M.P.Drahomanova. Kyiv, 1999. $22 \mathrm{~s}$

10. Dan McCreary, Ann Kelly. Making Sense of NoSQL: A guide for managers and the rest of us. Manning Publications, 2013. 312 p. ISBN 978-1-61729-107-4. science

Features of the course "Design and development of databases" for future teachers of computer

Yefymenko V.V.

Abstract. Some aspects of the methodology of teaching databases in the pedagogical university are considered in the article as the necessary component of professional training of specialists in the field of informatics. The group of questions of the theoretical content was investigated and a methodology for carrying out laboratory works on the course "Design and development of databases" was proposed. Particular attention is paid to the study of issues related to network model databases. Examples of such databases are considered.

Keywords: database, network model of databases, database management system, technology of data processing.

DOI 10.31392/NPU-nc.series 2.2019.21(28).13

УДК 81'322:510.567

Н.П. Франчук

кандидат педагогічних наук, доцент

Національний педагогічний університет імені М.П. Драгоманова

\title{
ТЕОРЕТИЧНІ АСПЕКТИ НАВЧАННЯ «ЛІНГВІСТИЧНОЇ ІНФОРМАТИКИ» ЯК ПРИКЛАДНОЇ ЛІНГВІСТИЧНОЇ ДИСЦИПЛІНИ
}

Анотація. В статті описано деякі аспекти розвитку сучасної прикладної лінгвістики. Розкрито зміст навчальної дисципліни «Лінгвістична інформатика». Описано п'яти компонентну методичну систему навчання дисципліни «Лінгвістична інформатика» як спецкурсу для учнів.

Ключові слова: лінгвістична інформатика, методична система навчання, спецкурсу для учнів.

Для успішного розвитку сучасного інформаційного суспільства необхідно формувати готовність викладачів та вчителів впроваджувати нові інформаційно-комунікаційні технології на якісно новому рівні, зважаючи на лінгвістичне підгрунтя. Сьогодні особливо гострою $\epsilon$ проблема формування системи інформатичних знань, умінь та навичок сучасних вчителів-предметників. Ця проблема пов'язана з бурхливим розвитком інформаційно-комунікаційних технологій та ї поширенням i використанням в різних галузях людської діяльності, пов'язаної 3 пошуком, опрацюванням, зберіганням, передаванням і захистом різноманітних повідомлень і даних.

Лінгвістична інформатика $\epsilon$ одним із найперспективніших напрямків розвитку сучасної прикладної лінгвістики. Як відносно нова лінгвістична галузь знань, становлення лінгвістичної інформатики розпочалося у 60-тих роках XX століття у зв'язку з інтенсивною комп'ютеризацією всіх 
галузей діяльності людей [3]. За ці роки в галузі лінгвістичної інформатики отримано значні як наукові, так і практичні результати: створено системи машинного перекладу текстів 3 одних природних мов на інші мови, системи автоматизованого пошуку даних в текстах, системи автоматичного аналізу та синтезу мовлення. 3 кожним роком перелік досягнень збільшується, адже рівень досконалості обчислювальної техніки постійно зростає.

Напрацювання в галузі лінгвістичної інформатики також сприяють розвитку штучного інтелекту. Розвиток процесу комп'ютеризації людської діяльності полягає в економії часу і зусиль, для цього значну частину рутинної роботи необхідно перекласти на машинну систему. Лінгвістична інформатика - це вивчення принципів побудови моделей, в яких відображаються конкретні процеси мовленнєво-розумової діяльності людини в конкретних ситуаціях. Тобто, це такі інформаційні системи, за допомогою яких можна моделювати та аналізувати тексти, зберігати і опрацьовувати дані та приймати рішення [3].

3 кожним роком виникає все більше і більше питань, пов'язаних з лінгвістичною інформатикою. Існують інші способи розв'язування проблем, пов'язаних 3 певними аспектами лінгвістичної інформатики:

1. Аналіз текстів природною мовою. Напрямок аналізу текстів природною мовою з'явився у зв'язку з бажанням розв'язати проблему машинного перекладу. Машинний переклад - це автоматичний переклад текстів 3 однієї мови на іншу, а також науковий напрямок, де охоплюється коло проблем, які виникають під час автоматизації перекладу [2]. До систем машинного перекладу зазвичай включаються лінгвістичні описи вхідної і вихідної мови, тобто мови вихідного тексту і тексту, отриманого в результаті перекладу, і алгоритм, на основі якого виконується даний переклад. 3 часом (у 50-х pp. XX ст.) проблема машинного перекладу переросла в окрему науково-технічну проблему і фактично набула ознак окремого наукового напрямку. Цей напрямок виник на стику таких наук, як математика, кібернетика, лінгвістика та програмування. Основу машинного перекладу як наукового напрямку складають результати, отримані в галузі комп'ютерної лінгвістики [2].

2. Синтез текстів природною мовою. В даний час автоматичний синтез текстів необхідний для створення:

- «інтелектуальних» систем, 3 використанням яких можна пояснювати користувачеві хід розв'язування тієї чи іншої задачі;

- систем підтримки прийняття рішень, з використанням яких можна допомагати користувачеві прийняти певне рішення;

- інформаційно-довідкових систем різного призначення, з використанням яких можна підказати користувачеві раціональний шлях пошуку або замовлення тих чи інших даних (наприклад, в системах замовлення квитків).

3. Розуміння текстів. Проблема розуміння текстів природною мовою включає не тільки лінгвістичні аспекти. 3 нею тісно пов'язані завдання, що традиційно в рамках психології, філософії та семіотики. Інструментом для розуміння змісту тексту служить аналіз текстів [4].

4. Інтелектуальний аналіз даних. Це один з наймолодших напрямків у комп'ютерній лінгвістиці. Поява цього аспекту пов'язана 3 інтенсивним використанням персональних комп'ютерів, використання яких вперше дало можливість організувати спілкування 3 користувачем не тільки шляхом обміну текстами, але і за допомогою зорових образів на екрані дисплея. Існують експериментальні моделі цього процесу та системи штучного інтелекту, 3 використанням яких можна описувати у вигляді тексту запропонований рисунок чи картинку, а також відтворювати одну з можливих картин, що відповідас введеному в систему тексту.

5. Моделі комунікаиії. Прикладами можуть бути:

- спосіб побудови повного діалогу на основі тих цілей, які ставляться в діалозі;

- підтримка обраного діалогу з врахуванням певних інтересів щодо його ведення [2].

Опрацювання природної мови $є$ важливим напрямом досліджень в галузі штучного інтелекту, що грунтується на обчислювальній лінгвістиці й потребує подальших міждисциплінарних розробок. Ключовими дослідженнями у цій галузі є розуміння, продукування мовлення, вивчення мови, що відображають класичні завдання інтелекту, такі як: сприйняття, комунікація, знання, планування, мислення та навчання.

Вивчення дисципліни «Лінгвістична інформатика» у Національному педагогічному університеті імені М.П. Драгоманова на факультеті інформатики для студентів спеціальності 014.09 Середня освіта (інформатика) базується на принципі професійної спрямованості, за яким передбачається створення відповідного навчально-інформаційного середовища, адекватного майбутньому професійному рівню фахівця 3 інформаційного забезпечення широкого спектру видів суспільної практики. 
Основними завданнями навчання дисципліни «Лінгвістична інформатика» $є$ :

- розширити та доповнити коло базових питань, які студенти вивчали раніше, такі як: характеристики програмних засобів сучасних інформаційно-лінгвістичних технологій, різновиди електронних словників, програми машинного перекладу та ін.;

- сформувати у студентів розуміння особливостей розвитку науки «Лінгвістична інформатика) на сучасному етапі, засвоєння основних методів стандартизації та систем показників якості програмних засобів;

- сформувати у студентів достатні знання, вміння і навички необхідні для проведення якісного оцінювання особливостей структури потоків даних та каналів їх надходження, на основі чого забезпечується професійна діяльність;

- виховати у студентів творчий підхід до розв'язування проблем стосовно уміння працювати 3 професійно важливими даними, тобто здійснювати їх аналіз та систематизацію;

- використовувати сучасні інформаційно-лінгвістичні технології для розпізнавання процесів, об'єктів та явищ сучасного інформаційного простору;

- розкрити місце і значення знань з сертифікації, стандартизації та захисту програмних засобів, стандартів з інформаційної безпеки, нормативно-правові засоби захисту даних;

- розвинути навички самостійної роботи для забезпечення методично доцільного використання та добирання потрібних програмних засобів для виконання конкретних завдань;

- розвинути здатність і відчуття необхідності постійного самовдосконалення і самоосвіти [5].

В процесі навчання дисципліни «Лінгвістична інформатика» необхідно розкрити якомога детальніше такі ії напрями, як:

- машинний переклад (процес перетворення тексту за допомогою комп'ютерних програм);

- автоматичне реферування (створення короткого опису матеріалів);

- «діалогові» системи (моделювання процесу спілкування людей, будування «діалогу»в стилі запитання-відповідь);

- корпусна лінгвістика (формування корпусів текстів чи баз даних та їх аналіз із використанням сучасних комп'ютерних технологій).

Зміст навчання дисципліни подається через два змістові модулі: Комп'ютерна лінгвістика та Лінгвістична інформатика й лінгвістичні бази знань та розміщена в системі MOODLE для студентів за посиланням: http://www.moodle.fi.npu.edu.ua/course/view.php?id=409 (Рис. 1). Доступ до цього курсу здійснюється за паролем або за реєстрацією на курс особисто викладачем.

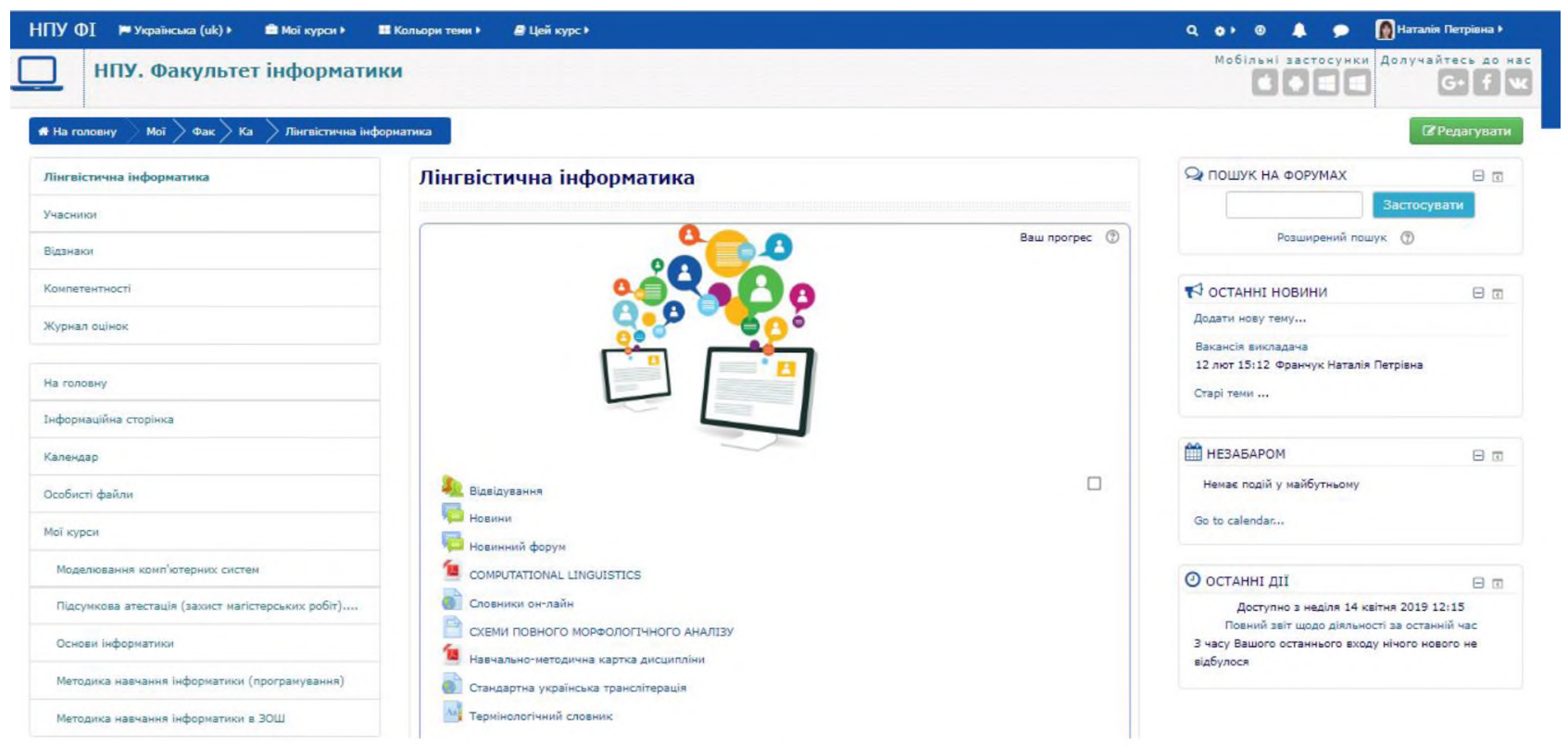

Puc. 1

Під час навчання потрібно звернути особливу увагу на основні тенденції розвитку інформаційнокомунікаційних технологій, зокрема мовно-інформаційних комп'ютерних систем, дати базові терміни та ознайомити з основним принципами машинного перекладу, аналізу тексту, синтезу тексту, побудови моделі, побудови словникових статей та ін. та вимогами до лінгвістичних програмних засобів - словників, баз даних, тезаурусів, систем машинного перекладу та ін. В процесі виконання лабораторних робіт студенти повинні навчитися: розрізняти типи даних за різними ознаками; розмежовувати бази даних і бази знань; встановлювати типи лінгвістичних баз даних: словниково- та 
тексто-орієнтовані; з'ясовувати тип лінгвістичної комп'ютерної системи; використовувати електронні словники з метою знайти потрібні лінгвістичні дані.

Лінгвістична інформатика - це дисципліна, в якій поєднується фундаментальність, теорію та практику. 3 використанням комп'ютера можна якісно покращити методи та прийоми аналізу й синтезу мовних даних, а також розв'язувати теоретичні задачі сучасного мовознавства й одержувати відомості про будову та функціонування мовних об'єктів. А отже можна стверджувати, що це самостійна лінгвістична дисципліна, в якій вивчаються і розв'язуються теоретичні й прикладні задачі мовознавства з використанням різних програмних засоб̈ів та комп'ютера загалом [1].

Процес формування у майбутніх вчителів інформатики знань і умінь стосовно використання комп'ютера в галузі лінгвістичної інформатики проходить під час ознайомлення з такими темами як:

- Розвиток лінгвістично-інформаційних технологій.

- Технології комп'ютеризованого перекладу.

- Предмет і завдання корпусної лінгвістики.

- Лінгвістичний алгоритм і лінгвістичний процесор.

- Використання мережі Інтернет у лінгвістичних дослідженнях.

- Системи машинного перекладу. Класифікація систем автоматизованого перекладу.

- Мовні дані.

- Бази даних і бази знань.

- Структурування та формалізація мовних даних.

- Автоматизоване опрацювання повідомлень природною мовою.

- Комп'ютерні лінгвістичні системи.

- Комп'ютерна лексикографія.

- Інтегрована лексикографічна система «Словники України».

- Корпуси текстів: основні типи і структура.

- Сучасні напрямки досліджень і розробок.

- Семантичне моделювання.

- Моделі подання знань.

- База знань.

- Електронні словники.

Після засвоєння вищеназваних тем студенти 3 легкістю можуть: встановлювати тип і пояснювати причини помилок машинного перекладу; застосовувати пошукові системи мережі Інтернет 3 метою лінгвістичних досліджень; за технічними вимогами вибрати структуру або розробити комп'ютерну систему, ïi складові, визначити режими їі функціонування та оцінити спроектовану систему.

На сьогодні практично кожен студент має мобільний пристрій, через який можна отримати доступ до глобальної мережі Інтернет, та різноманітні програмні засоби, зокрема і програмиперекладачі чи програми-словники. Це дає змогу швидко знаходити потрібні дані і за потреби робити автоматичний переклад тексту. Адже мова $є$ самодостатньою системою, яка постійно розвивається $\mathrm{i}$ вдосконалюється у взаємозв'язках з розвитком суспільства. 3 розвитком технологій з'являються відповідні слова і словосполучення, за допомогою яких можна пояснити певний раніше невідомий процес, об’єкт чи явище. Мова дуже схожа з математикою, бо також застосовується у всіх галузях людської діяльності. Відрізняється лише ознаками (цифри мають кількісну ознаку, а слова - кілька ознак). Щоб добре володіти мовою, потрібно постійно практикуватися i збільшувати свій словниковий запас. Студентам можна запропонувати встановити певні програми для кращого засвоєння та практичного застосування матеріалу. Це дасть змогу краще засвоїти тему «Використання лінгвістичних ресурсів в глобальній мережі Інтернет». Разом 3 тим можна запропонувати долучитися до спільноти перекладачів (Google Перекладач), чим допомогти покращити переклади для мільйонів користувачів.

Останнім часом стали актуальними проблеми визначення рівня володіння іноземною мовою відповідно до європейських мовних стандартів. Студенти також жваво обговорюють ці питання, зокрема: «Де можна перевірити рівень знань іноземної мови?», «Які існують рівні володіння мовою?», «Чим відрізняється один рівень від іншого» та інші. На такі питання слід звернути увагу в процесі навчання дисципліни «Лінгвістична інформатика». Для початку доцільно дати теоретичні відомості про основні шість рівнів володіння іноземною мовою:

- Al. Елементарний (Elementary / Beginning Level);

- А2. Базовий (Basic / Pre-intermediate Level);

- B1. Пороговий (Intermediate Level);

- B2. Середній (Upper-intermediate Level);

- C1. Прогресивний (Advanced / Proficiency Level);

- C2. Досвідчений (Master / Proficiency Level). 
Доцільно запропонувати студентам різноманітні сайти для визначення їхнього рівня володіння іноземною мовою. Наприклад, на сайті www.onset.de можна швидко та точно перевірити рівень володіння англійською чи німецькою мовами.

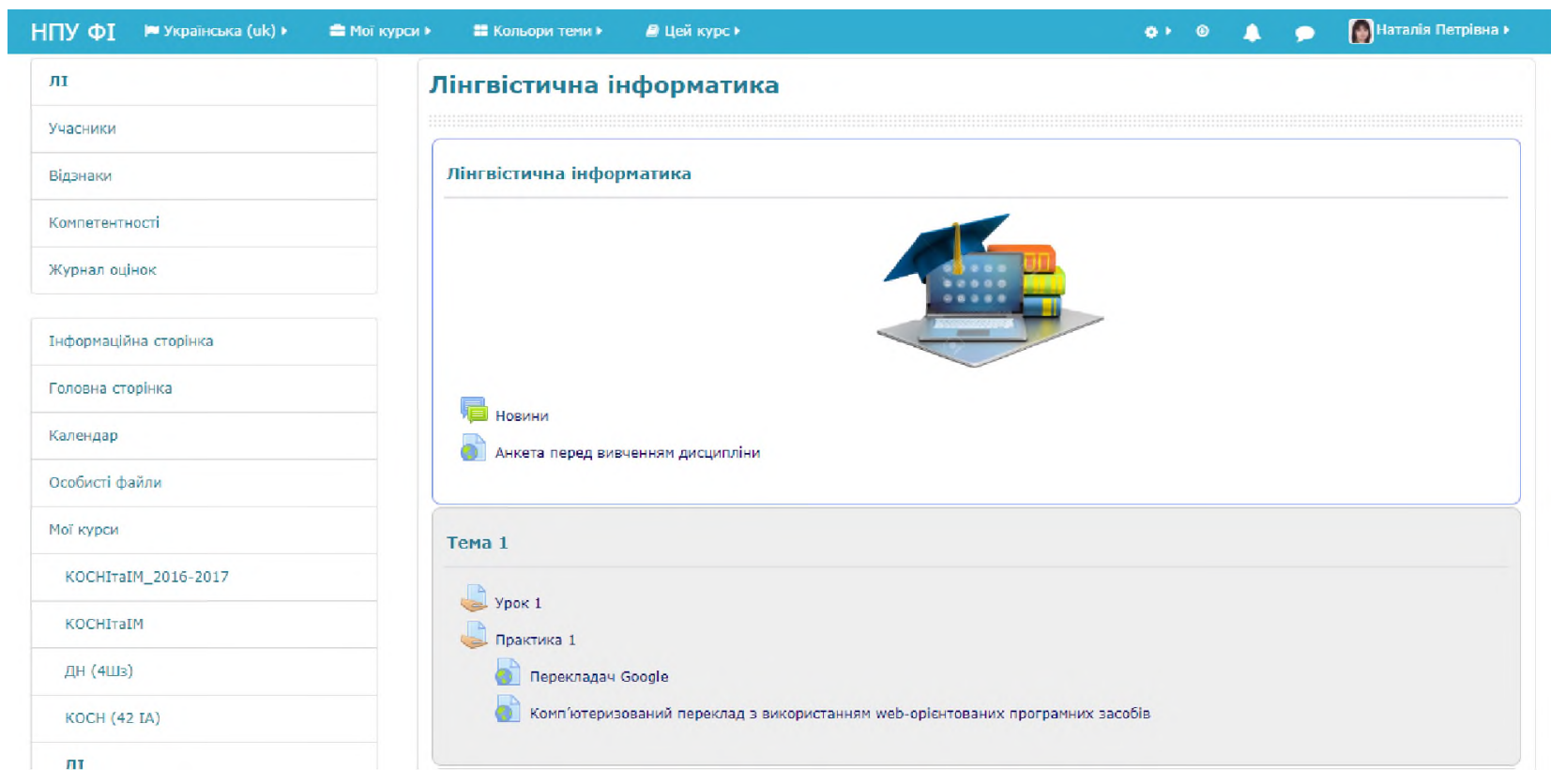

Puc. 2

В спрощеному вигляді дану дисципліну було запропоновано як факультатив для учнів і теж розміщено в системі MOODLE за посиланням: http://www.moodlestudent.fi.npu.edu.ua/course/view.php?id=214 (Рис. 2). Доступ до цього курсу здійснюється за реєстрацією на курс особисто вчителем або за паролем. Рівень знань, якого мають досягти учні, 3 кожним роком підвищується. Тому постає необхідність в проведенні експериментальних спроб навчання учнів основ лінгвістичної інформатики.

Спираючись на п'яти компонентну систему навчання було розроблено та впроваджено методичну систему навчання основ лінгвістичної інформатики в якій цілями навчання були:

- набуття учнями знань 3 нової для них галузі - лінгвістичної інформатики, що значним чином розширює їхні можливості в роботі з інформаційно-комунікаційними технологіями;

- формування знань і вмінь, необхідних для розуміння змісту навчального матеріалу дисципліни;

- розвинути навички самостійної роботи;

- використовувати сучасні інформаційно-лінгвістичні технології для пізнання об’єктів, процесів та явищ сучасного інформаційного простору.

Що стосується змісту навчання, то даний курс складається 3 п'яти лабораторних робіт, п'яти лекцій, проміжного та підсумкового (залікового) тесту. Кожне заняття лабораторної роботи та лекції структуроване та знаходяться в окремих блоках. В тесті містяться завдання різного формату та вказано часовий проміжок для виконання.

Засобами навчання даного спецкурси були:

пакет програм для подання навчального матеріалу та контролю знань;

- програми-перекладачі;

- програми для роботи з текстовими даними.

Крім традиційних методів навчання лінгвістичної інформатики, таких як: пояснювальноілюстративний, практичний, частково-пошуковий, дослідницький, репродуктивний, під час навчання основ лінгвістичної інформатики використовувались і методи інтерактивного навчання (акваріум, робота в малих групах, карусель, метод проектів). Зокрема: технологію акваріум доцільно використовувати на лекції чи диспуті. Наприклад, під час вивчення теми «Системи машинного перекладу» перед учням постала проблема: «Який програмний засіб для перекладу тексту можна використати під час перекладання математичних текстів 3 формулами?» Після жвавого обговорення учні дійшли висновку, що найкращим онлайн перекладачем $\epsilon$ Google Перекладач, а стаціонарним програма Pragma.

Формами навчання були: лекції; лабораторні роботи; тестування

Використання запропонованих окремих теоретичних аспектів в процесі навчання дисципліни «Лінгвістична інформатика) як прикладної дисципліни, під час підготовки як студентів 
інформатичних спеціальностей педагогічних закладів вищої освіти, так і учнів закладів загальної середньої освіти, сприятиме доцільному набуттю фахових знань, що дасть змогу ефективно використовувати комп'ютерні технології в майбутній професійній діяльності

Список використаних джерел:

1. Карпіловська Є.А. Вступ до прикладної лінгвістики: комп'ютерна лінгвістика: підруч. Донецьк: ТОВ «Юго-Восток, Лтд». 2006. 188 с.

2. Лінгвістичні основи комп'ютерної техніки. URL:

https://otherreferats.allbest.ru/languages/00117518_0.html (дата звернення: 17.03.2019).

3. Навчально-методичний комплекс навчальної дисципліни «Прикладна лінгвістика». URL: http://fif.mdu.edu.ua/wp-content/uploads/2017/07/Prikladna-lingvistika-1-kurs.pdf (дата звернення: 17.03.2019).

4. Основи прикладної лінгвістики: вступ до спеціальності. URL: http://elar.khnu.km.ua/jspui/bitstream/123456789/6085/1/текст\%20друк\%20192\%20c.-3.doc） (дата звернення: 17.03.2019).

5. Навчальна програма з дисципліни «Лінгвістична інформатика». / упоряд.: Н.П. Франчук. Київ: НПУ імені М.П. Драгоманова. 2018. 20 с

\section{References:}

1. Karpilovs'ka YE.A. Vstup do prykladnoyi linhvistyky: komp"yuterna linhvistyka: pidruch. Donets'k: TOV «Yuho-Vostok, Ltd», 2006. 188 s.

2. Linhvistychni osnovy komp'yuternoyi tekhniky. URL: https://otherreferats.allbest.ru/languages/ 00117518_0.html (data zvernennya: 17.03.2019).

3. Navchal'no-metodychnyy kompleks navchal'noyi dystsypliny «Prykladna linhvistyka». URL: http://fif.mdu.edu.ua/wp-content/uploads/2017/07/Prikladna-lingvistika-1-kurs.pdf (data zvernennya: 17.03.2019).

4. Osnovy prykladnoyi linhvistyky: vstup do spetsial'nosti. URL: http://elar.khnu.km.ua/jspui/ bitstream/123456789/6085/1/текст\%20друк\%20192\%20c.-3.doc (data zvernennya: 17.03.2019).

5. Navchal'na prohrama z dystsypliny «Linhvistychna informatyka». / uporyad.: N.P. Franchuk. Kyyiv: NPU imeni M.P. Drahomanova. 2018. $20 \mathrm{~s}$.

Theoretical aspects of the study of "linguistic informatics" as an applied linguistic discipline Franchuk N.P.

Abstract. This paper some aspects of development of modern applied linguistics. Disclosed content of the academic discipline "Linguistic Informatics". Described five component methodical system of training course "Linguistic science" as a special course for students.

Keywords: linguistic informatics, methodical system of training, special course for students.

DOI 10.31392/NPU-nc.series 2.2019.21(28).14

УДК: 378.147/.148+373.51

О.Н. Кушнір

кандидат педагогічних наук, доцент, декан факультету комп'ютерних наук, фізики та математики

Херсонський державний університет;

В.В. Шакотько

кандидат педагогічних наук, заступник директора з навчальної роботи

Кременчуцький педагогічний коледж імені А.С. Макаренка

\section{ФОРМУВАННЯ АЛГОРИТМІЧНИХ КОМПЕТЕНТНОСТЕЙ МАЙБУТНІХ УЧИТЕЛІВ ІНФОРМАТИКИ НА НОВОМУ ЕТАПІ РОЗВИТКУ ОСВІТИ}

Анотація. У статті проаналізовано погляди вчених на алгоритмічну складову підготовки майбутніх вчителів інформатики, досліджені зв'язки змісту вимог до фахових компетентностей вчителів інформатики та змісту навчальних програм шкільної інформатики на різних етапах розвитку цієї навчальної дисципліни.

Проведено порівняльний аналіз вимог до рівня сформованості алгоритмічних компетентностей учнів середньої школи за програмами інформатики 2008-2009 років та 2017-2018 років. На основі цього аналізу, а також результатів моніторингу рівня підготовленості вчителів до навчання учнів алгоритмізації та програмування обгрунтована необхідність внесення суттєвих змін в методичну 